5. Піблічний звіт голови Державного агенства рибного господарства України Ганник Шишман за 2020 р. URL: https://darg.gov.ua/_publichnij_zvit_golovi_0_0_0_10694_1.html

DOI https://doi.org/10.30525/978-9934-26-047-6-16

\title{
ЕКОЛОГІЧНІ МЕТОДИ ВІДНОВЛЕННЯ ЗЕМЕЛЬ, ЗАБРУДНЕНИХ НАФТОПРОДУКТАМИ
}

\author{
Головань Л. В. \\ кандидат сільськогосподарських наук, \\ завідувач кафедри екології та біотехнології, \\ дочент кафедри екології та біотехнології
}

Харківський наџіональний аграрний університет імені В. В. Докучаєва

\section{Бузіна I. М.}

кандидат сільськогосподарських наук, доцент, дочент кафедри екологї та біотехнології

Харківський національний аграрний університет імені В. В. Докучаєва

\section{Чуприна Ю. Ю.}

стариий викладач кафедри екології та біотехнології Харківський національний аграрний університет імені В. В. Докучаєва м. Харків, Україна

Розвиток нафтовидобутку і нафтовиробництва супроводжуються збільшенням масштабів і зростанням обсягів нафтових забруднень $\mathrm{i}$ відходів, що викликають наростання екологічної загрози, зменшення площ господарських угідь, зниження родючості грунтів і погіршення здоров'я населення. Існуючі технології ліквідації нафтових забруднень виявляються малоефективними і високовитратними та не відповідають сучасним вимогам екології.

Існує декілька методів ліквідації розливу нафтопродуктів: механічні, термічні, фізико-хімічні; біологічні. На сьогодні механічні методи очищення грунтів, забруднених нафтою $є$ найбільш поширеними, проте вони мають істотні недоліки. Тому розробка і вдосконалення технологій біоремедіації грунтів нині $€$ важливим екологічним завданням. 
Термічний метод, який грунтується на випалюванні шару нафти, застосовується при достатній товщині шару і безпосередньо після забруднення, до утворення емульсій з водою. Цей метод, як правило, застосовується у поєднанні з іншими методами ліквідації розливу.

Фізико-хімічний метод з використанням диспергентів і сорбентів розглядається як ефективний в тих випадках, коли механічний збір нафти та нафтопродуктів (ННП) неможливий, наприклад при малій товщині плівки або коли ННП, що розлилися, представляють реальну загрозу найбільш екологічно уразливим районам.

Біологічний метод використовується після застосування механічного і фізико-хімічного методів при товщині плівки не менше 0,1 мм. Біологічні методи очищення грунту від нафтових забруднень полягають у застосуванні активних мікробних штамів, що проявляють здатність рости і використовувати в якості джерела вуглецю і енергії вуглеводні нафти, отримали сьогодні широкий розвиток і застосування. За сприятливих умов середовища (оптимальна температура, солоність, $\mathrm{pH}$, достатня міра аерації, забезпеченість елементами мінерального живлення) вдало підібрана культура або суміш штамів здатні за короткий час практично повністю утилізувати десятки тон нафтових вуглеводнів, що трансформували, зокрема, в органічну речовину власної біомаси, вуглекислий газ і нешкідливі для довкілля, продукти. Процес деструкції нафтового забруднення протікає в період від декількох днів або тижнів до декількох місяців, залежно від міри забруднення об'єкту, хімічного складу забрудника, кліматичних і фізико-хімічних параметрів середовища [1].

Іншим перспективним методом для очищення вуглеводневих забруднень у промислово розвинених країнах є фіторемедіація очищення грунту за допомогою рослин. Основною перевагою цього методу є його найбільша економічна ефективність у порівнянні з усіма вищезгаданими при збереженні того ж рівня ефективності очищення. Порівнюючи його 3 мікробіологічними методами можна сказати, що вони ефективніші для водойм, тоді як рослини краще використати для очищення грунтів [2].

У всіх заходах, пов'язаних 3 ліквідацією наслідків нафтового забруднення, з відновленням порушених земель, необхідно виходити 3 головного принципу: не нанести екосистемі більшої шкоди, ніж та, яку вже завдано при забрудненні.

Використання сорбентів при ліквідащії нафтових забруднень. Існування великих промислових родовищ алюмосилікатних сорбентів, наявність ефективних методів регулювання їх геометричної структури $\mathrm{i}$ хімічної природи поверхні, низька вартість робить їх використання економічно вигідним. Зараз у світі виробляється або використовується близько 200 видів сорбентів для ліквідації забруднень нафтового 
походження, які можна класифікувати за різними ознаками: походженням, дисперсністю, призначенням, за способом утилізації. Якість сорбентів визначається, головним чином, їх ємністю по відношенню до нафти, ступенем гідрофобності, плавучістю після сорбції нафти або нафтопродуктів, можливістю десорбції, регенерації або утилізації сорбенту.

Існуюча екологічна ситуація вимагає розробки спеціальних норм захисту біосфери від забруднень вугливоднями. На сьогоднішній день існує значний арсенал методів ліквідації поверхневих забруднень. Аналіз літературних джерел стосовно очистки нафтовмісних вод показує високу ефективність застосування сорбційного методу. Гостро стоїть питання про доцільність організації сорбентів з місцевої сировини і відходів, що дозволить не лише оперативно вирішити екологічні проблеми, пов'язані 3 потрапляннями нафтопродуктів у стічні води, але і забезпечить істотний економічний прибуток, оскільки виробництво сорбентів надзвичайне вигідно при сформованому попиті [3].

Очевидно, краще вжити певних заходів для того, щоб запобігти забрудненню земель та водойм нафтою та нафтопродуктами, ніж займатися ліквідацією такого забруднення. Для запобігання забруднення грунтів при проектуванні об’єктів нафтопромислів передбачається:

- повна герметизація систем збору, сепарації та підготовки нафти і газу;

- автоматичне відключення свердловин відсікачами при прориві викидних лінії;

- покриття ізоляцією посиленого типу магістральних нафтопроводів 3 100\%-им просвічуванням стиків на переходах через штучні та природні перешкоди;

- використання безстічних систем каналізації промислово-зливових і фекальних стоків;

- повне використання пластових і промислових стічних вод для закачування в продуктивні пласти і підтримання пластового тиску;

- внутрішне протикорозійне покриття трубопроводів, перекачувальних пластову воду.

Гірничотехнічна рекультивація земель на об'єктах нафтової промисловості виконується в суворій відповідності до затверджених проектів на будівництво конкретного об'єкта (трубопроводу, установки 3 підготовки нафти і т. д.) [4].

\section{Література:}

1. Пітерс А. Розливи нафти та навколишнє середовище. 2006. № 4. C. 11. 
2. Молотков И.В., Касьяненко В.А. Фиторемедиация / Нефть. Газ. Промышленность. 2005. № 1 (13). С. 4-6.

3. Максимюк М.P., Міцкевич Д.І., Міцкевич А.І. Нафтове забруднення поверхневих вод та шляхиподолання його наслідків / Наукові праці. Техногенна безпека. 2014. Т. 233. Вип. 221. С. 37-40.

4. Гринчишин Н.М., Бабаджанова О.Ф. Реабілітація грунтів, забруднених аварійними виливами нафтопродуктів / Науковий вісник НЛТУ. 2012. Вип. 22.7. С. 43-49.

DOI https://doi.org/10.30525/978-9934-26-047-6-17

\title{
ФОСФОРНО-КАЛЬЦІЕВА ПРОБЛЕМА УКРАЇНСЬКИХ ГРУНТІВ ТА ШЛЯХИ ЇЇ ВИРІШЕННЯ
}

\author{
Гуменюк Г. Б. \\ кандидат біологічних наук, \\ доиент кафедри загальної біологіі \\ та методики навчання природничих дисциплін \\ Тернопільський національний педагогічний університет \\ імені Володимира Гнатюка \\ м. Тернопіль, Україна \\ Волошин О. С. \\ кандидат біологічних наук, \\ доиент кафедри загальної біології \\ та методики навчання природничиї дисичилін \\ Тернопільський національний педагогічний університет $i$ \\ мені Володимира Гнатюка \\ м. Тернопіль, Украӥна

\section{Зіньковська Н. Г.} \\ кандидат біологічних наук, \\ дочент кафедри біології, екології та методики їх навчання \\ Кременеиька обласна гуманітарно-педагогічна академія \\ імені Тараса Шевченка \\ м. Кременець, Тернопільська область, Украӥна
}

В степовій та лісостеповій зоні України, особливо в посушливі роки, першим за важливістю елементом мінерального живлення 